\section{Casting a lure for EGFR ligands}

\section{By Michael J. Haas, Senior Writer}

Researchers at The University of Texas M.D. Anderson Cancer Center have identified an EGFR-mimicking peptide that lures ligands away from the receptor, thus preventing its activation and halting tumor growth. ${ }^{1}$ Although toxicity and pharmacokinetic studies are still pending, this decoy should be cheaper to manufacture than EGFR-targeting antibodies and could have greater specificity than small molecules.

Epidermal growth factor receptor (EGFR) is overexpressed in many cancers, in which activation by its endogenous ligands, such as epidermal growth factor (EGF) and transforming growth factor- $\alpha$ (TGFA; TGF- $\alpha$ ), aids tumor cell growth and proliferation. EGFRtargeting cancer therapies on the market or in development are either antibodies or small molecule kinase inhibitors that bind the receptor to prevent its activation (see Table 1, "Advanced EGFR space").

A team co-led by M.D. Anderson researchers Renata Pasqualini and Wadih Arap originally set out to map the binding epitope of Erbitux cetuximab, an anti-EGFR antibody marketed by Eli Lilly and Co. to treat head and neck cancer and metastatic colorectal cancer.

They looked for peptides that could bind cetuximab, EGF and TGF- $\alpha$, which thus would help define the antibody's EGFR-binding epitope. In the process, the team identified an EGFR-mimicking peptide with biological effects on cancer. According to Pasqualini, this discovery came as a bonus.

Pasqualini is professor of medicine and experimental diagnostic imaging and Arap is deputy chairman of genitourinary medical oncology and professor of medicine and experimental diagnostic imaging.

The team, which also included researchers from Harvard Medical School and Beth Israel Deaconess Medical Center, used phagedisplay screening and competitive binding assays to search a combinatorial library of eight-amino-acid L-peptides that could bind cetuximab, EGF and TGF- $\alpha$.

When they identified a peptide that bound all three molecules and were able to further narrow the interacting site to a pentameric L-peptide, they realized they might have a therapeutic that could work much like Regeneron Pharmaceuticals Inc.'s VEGF Trap, a fusion protein that targets VEGF receptor ligands. VEGF Trap is in

Table 1. Advanced EGFR space. Selected therapies targeting epidermal growth factor receptor (EGFR) activation to treat cancer. Source: BCIQ: BioCentury Online Intelligence

\begin{tabular}{|c|c|c|c|c|c|}
\hline Company & Product name & Description & Target(s) & Lead indication(s) & Lead status \\
\hline $\begin{array}{l}\text { Amgen Inc. (NASDAQ:AMGN)/ } \\
\text { Takeda Pharmaceutical Co. Ltd. } \\
\text { (Tokyo:4502) }\end{array}$ & Vectibix panitumumab & Antibody & $\begin{array}{l}\text { EGF receptor } 1 \\
\text { (HER1; ERBB1) }\end{array}$ & Colorectal cancer & Marketed \\
\hline $\begin{array}{l}\text { AstraZeneca plc } \\
\text { (LSE:AZN; NYSE:AZN) }\end{array}$ & Iressa gefitinib & Small molecule & HER1 & $\begin{array}{l}\text { Non-small cell lung } \\
\text { cancer (NSCLC) }\end{array}$ & Marketed \\
\hline $\begin{array}{l}\text { Eli Lilly and Co. (NYSE:LLY)/ } \\
\text { Bristol-Myers Squibb Co. } \\
\text { (NYSE:BMY)/Merck KGaA } \\
\text { (Xetra:MRK) }\end{array}$ & Erbitux cetuximab & Antibody & HER1 & $\begin{array}{l}\text { Colorectal cancer; } \\
\text { head and neck cancer }\end{array}$ & Marketed \\
\hline $\begin{array}{l}\text { Genentech Inc./Roche } \\
\text { (SIX:ROG; OTCQX:RHHBY) }\end{array}$ & Herceptin trastuzumab & Antibody & HER2 (ERBB2; neu) & Breast cancer & Marketed \\
\hline $\begin{array}{l}\text { GlaxoSmithKline plc } \\
\text { (LSE:GSK; NYSE:GSK) }\end{array}$ & Tyverb/Tykerb lapatinib & Small molecule & HER1; HER2 & Breast cancer & Marketed \\
\hline $\begin{array}{l}\text { OSI Pharmaceuticals Inc. } \\
\text { (NASDAQ:OSIP)/Genentech/Roche }\end{array}$ & Tarceva erlotinib & Small molecule & HER1 & $\begin{array}{l}\text { NSCLC; pancreatic } \\
\text { cancer }\end{array}$ & Marketed \\
\hline $\begin{array}{l}\text { YM BioSciences Inc. (TSX:TM; } \\
\text { NYSE-A:YMI)/CIMAB S.A. }\end{array}$ & Theraloc nimotuzumab & Antibody & HER1 & $\begin{array}{l}\text { Brain cancer; head } \\
\text { and neck cancer }\end{array}$ & $\begin{array}{l}\text { Marketed in various } \\
\text { countries including } \\
\text { Brazil, China and India; } \\
\text { Phase III in U.S./EU }\end{array}$ \\
\hline AstraZeneca & $\begin{array}{l}\text { Zactima vandetanib } \\
\text { (ZD6474) }\end{array}$ & Small molecule & $\begin{array}{l}\text { HER1; VEGF receptor } 2 \\
\text { (KDR/FLK-1; VEGFR2) }\end{array}$ & Thyroid cancer & Phase III \\
\hline Boehringer Ingelheim GmbH & Tovok (BIBW 2992) & Small molecule & HER1; HER2 & NSCLC & Phase III \\
\hline Eli Lilly & Necitumumab (IMC-11F8) & Antibody & HER1 & NSCLC & Phase III \\
\hline Genmab A/S (CSE:GEN) & Zalutumumab & Antibody & HER1 & Head and neck cancer & Phase III \\
\hline Genentech/Roche & Pertuzumab (RG1273) & Antibody & HER2 & Breast cancer & Phase III \\
\hline
\end{tabular}


Phase III testing to treat metastatic prostate cancer, metastatic colorectal cancer and metastatic non-small cell lung cancer (NSCLC).

The team proceeded to show that the pentameric L-peptide inhibited cell proliferation in human colon and head and neck cancer cell lines.

Because native L-peptides are susceptible to rapid enzymatic degradation, the team also synthesized a D-peptide version to test in vivo. In mice with mammary tumors, the $\mathrm{D}$-peptide significantly reduced tumor growth compared with that in controls $(p=0.02)$ and did so more efficiently than the L-peptide.

The data were published in the Proceedings of the National Academy of Sciences.

\section{Springing the trap}

Despite the clear therapeutic gain from inhibiting EGFR using antibodies and small molecules, the former are costly to manufacture and require inconvenient injections, whereas the latter can have serious off-target effects due to a lack of specificity.

The soluble peptide decoy offers a third approach to modulating the receptor.

"A peptide could penetrate the tumor and get into the core better than an antibody," Michael Kragh, director of antibody pharmacology at Symphogen A/S, told SciBX. "It could also have a higher specificity for its target than a small molecule inhibitor."

A peptide would also be cheaper to manufacture than an antibody, he said.

Kragh also suggested that the decoy could potentially treat cancers that have developed resistance to EGFR-targeting therapies because the peptide targets EGF ligands rather than EGFR expressed on tumor cells.

Targeting ligands instead of the receptor "might also have some advantages in combination therapy," Kragh said. But he noted that the peptide could not be used together with cetuximab because it binds that antibody. "You would need to use the peptide in combination with antibodies that target a different EGFR epitope than cetuximab," he said.

Jan van de Winkel, president of R\&D and CSO of Genmab A/S, agreed with Kragh that a peptide could have better tumor penetration and lower manufacturing costs than an antibody.

But van de Winkel pointed out that a ligand-targeting agent might induce resistance in the cancer more readily than a receptor-targeting antibody.

"EGFR binds at least seven different endogenous ligands," he said. "One can speculate that blocking one or two ligands might eventually drive tumor cells to compensate by switching to another ligand," whereas blocking the receptor directly would limit the development of resistance by that mechanism.

Kragh wanted to know how the peptide stacks up against antibody therapeutics in vivo. "If I were doing this study, I would use as a comparator an antibody that had been on the market for a while and had well-known properties, such as cetuximab," he said.
Kragh and van de Winkel both noted that the decoy peptide's binding behavior and pharmacokinetics still need to be fleshed out.

Kragh also noted that the team only used one concentration of the peptide in its in vitro inhibition experiments. "It is not clear how much ligand the decoy can inhibit," he said.

"It would be important for the decoy to have a higher affinity than EGFR for the ligands" because the peptide is competing with the receptor for ligand binding, Kragh added. "Otherwise, the decoy could just serve as a reservoir of ligands that could transfer to the EGFR later."

van de Winkel noted that small peptides generally have lower binding affinities than antibodies or small molecule inhibitors for their respective targets and thus require higher doses to be effective. This would increase the peptide's potential for toxicity and could narrow its therapeutic window, he said.

Pasqualini said it wasn't necessary for the peptide to have high inhibitory concentrations in vitro to be effective in vivo. "As long as the toxicity profile is favorable, and one can manufacture and administer the peptide safely, the amounts needed aren't very important," she told SciBX.

Pasqualini also said that ultra-high binding affinity might not be desirable for the EGFR decoy. A peptide with high affinity for EGFR ligands would bind to every molecule of EGF and TGF- $\alpha$ it encountered-including those present in very low concentrations in normal

tissues, she said.

"Ultimately, if the biologically relevant endpoint can be achieved, then the properties extrapolated from in vitro settings are less relevant," Pasqualini said.

Kragh and van de Winkel said it would be helpful to know the half-life of the peptide because that would give some clues about the doses that might be required to treat human cancers. There were no data in the PNAS article about the peptide dosing regimen used to treat the mouse models of cancer.

According to Pasqualini, the team has not yet determined an optimal dosing regimen for the L- or D-peptide in mice. "Without extensive $\mathrm{R} \& \mathrm{D}$ and systematic approaches, in our experience it is very difficult to predict the best regimen and the best dose for a given compound" in mice or humans, she said.

van de Winkel noted that compared to therapeutic antibodies that have half-lives of two to three weeks, a small peptide would have a serum half-life of several hours. This would require frequent dosing of the peptide, which in turn might require a more convenient route of administration than injection-such as an oral formulation, he said.

Delivering a peptide orally "might be challenging with regards to bioavailability and stability relative to protease degradation, van de Winkel said.

Kragh agreed that oral administration of the peptide would be unlikely. But he said, "I think you could develop the peptide for subcutaneous or transdermal delivery-something the patient could use at home" to make treatment more convenient and less painful than 
an antibody or peptide injection in the clinic.

Symphogen has two therapies that target EGFR signaling in development. Sym004, a combination of two anti-EGFR mAbs against distinct, nonoverlapping epitopes in the extracellular domain III of EGFR, is in preclinical development to treat cancer. The company expects to begin a Phase I trial in metastatic colorectal cancer this quarter.

Sym011 (RBLX-242), a ligand trap consisting of the extracellular domains of EGFR and EGF receptor 3 (HER3; ERBB3) fused to the Fc region of human IgG1, is in discovery to treat cancer. Symphogen acquired both compounds from Receptor BioLogix Inc. in 2008.

Genmab's zalutumumab, a human mAb that locks EGFR in an inactive form and prevents receptor dimerization to inhibit EGFR signaling, is in Phase III testing to treat squamous cell carcinoma of the head and neck (SSCHN) in patients refractory to or intolerant of standard platinum-based chemotherapy.

\section{More peptide leads}

Pasqualini agreed that there needs to be more work-including toxicology studies - on the D-peptide. "We have not performed any pharmacokinetic or pharmacodynamic studies, but the half-life of the D-peptide is likely to be long and favorable" from a bioavailability standpoint, based on studies with other D-peptides, she said.

Meanwhile, Pasqualini pointed out that the methods her team used to develop the EGFR decoy could be used to identify peptides targeting other ligand-receptor interactions. "The conceptual framework for going from combinatorial screening to a therapeutic lead with favorable properties could be easily applicable to many different ligand-receptor systems," she said.

Indeed, another team led by Pasqualini and Arap has developed a D-peptide that binds VEGF receptor 1 (FLT1; VEGFR1) and neuropilin 1 (NRP1) to block angiogenesis in mouse models of cancer and retinopathy. ${ }^{2}$ That team included researchers from Federal University of Rio de Janeiro and the University of Michigan School of Dentistry and also published its findings in PNAS.

Pasqualini said the team expects that its FLT1- and NRP-binding VEGF mimic could be formulated as an eye drop rather than an injection for retinal indications and has physical properties that would favor low-cost manufacturing.

She said ongoing work includes testing the efficacy and safety of both the EGFR- and the VEGF-mimicking D-peptides in additional animal models of cancer. The team is also testing the VEGFmimicking D-peptide in other animal models of retinopathy.

Pasqualini said patent applications covering the findings reported in both PNAS papers have been filed and the IP is available for licensing.

Haas, M.J. SciBX 3(9); doi:10.1038/scibx.2010.266

Published online March 4, 2010

\section{REFERENCES}

1. Cardó-Vila, M. et al. Proc. Natl. Acad. Sci. USA; published online Feb. 15, 2010; doi:10.1073/pnas.0915146107

Contact: Renata Pasqualini, The University of Texas M.D. Anderson Cancer Center, Houston, Texas

e-mail: rpasqual@mdanderson.org

Contact: Wadih Arap, same affiliation as above

e-mail: warap@mdanderson.org

Contact: Richard L. Sidman, Beth Israel Deaconess Medical Center, Boston, Mass.

e-mail: richard_sidman@hms.harvard.edu

2. Giordana, R. et al. Proc. Natl. Acad. Sci. USA; published online

Feb. 22, 2010; doi:10.1073/pnas.0915141107

Contact: Wadih Arap, The University of Texas M.D. Anderson Cancer Center, Houston, Texas

e-mail: warap@mdanderson.org

Contact: Renata Pasqualini, same affiliation as above

e-mail: rpasqual@mdanderson.org

Contact: Richard L. Sidman, Beth Israel Deaconess Medical Center, Boston, Mass.

e-mail: richard_sidman@hms.harvard.edu

\section{COMPANIES AND INSTITUTIONS MENTIONED}

Beth Israel Deaconess Medical Center, Boston, Mass.

Eli Lilly and Co. (NYSE:LLY), Indianapolis, Ind.

Federal University of Rio de Janeiro, Rio de Janeiro, Brazil

Genmab A/S (CSE:GEN), Copenhagen, Denmark

Harvard Medical School, Boston, Mass.

Receptor BioLogix Inc., Palo Alto, Calif.

Regeneron Pharmaceuticals Inc. (NASDAQ:REGN), Tarrytown, N.Y.

Symphogen A/S, Copenhagen, Denmark

University of Michigan School of Dentistry, Ann Arbor, Mich.

The University of Texas M.D. Anderson Cancer Center, Houston, Texas 